\title{
ANALISIS LAPORAN ARUS KAS PADA LPD DESA PAKRAMAN PENGLATAN PERIODE 2013-2014
}

\author{
Kadek Yudiarta \\ Jurusan Akuntansi Program Diploma III, \\ Universitas Pendidikan Ganesha, Singaraja \\ yudiartak@yahoo.com
}

\begin{abstract}
Abstrak
Dalam mengawasi arus kas dibutuhkan laporan arus sehingga dapat diketahui perkembangan kas yang ada didalam LPD tersebut terkait dengan penerimaan kas maupun pengeluaran kas serta penilaian terhadap kegiatan usaha (operasi, investasi, dan pendanaan) yang terkait dengan kas. Penelitian ini bertujuan untuk mengetahui (1) laporan arus kas pada LPD Desa Pakraman Penglatan periode 2013-2014, dan (2) analisis laporan arus kas pada LPD Desa Pakraman Penglatan periode 2013-2014.

Objek dalam penelitian ini adalah laporan arus kas pada LPD Desa Pakraman Penglatan dan analisis laporan arus kas pada LPD Desa Pakraman Penglatan. Pengumpulan data menggunakan metode dokumentasi. Kemudian data yang telah dikumpulkan diolah dengan menggunakan analisis deskriptif kuantitatif.
\end{abstract}

Kata-kata kunci : Analisis, Laporan Arus Kas dan LPD Desa Pakraman Penglatan

\begin{abstract}
Cash is an asset most smoothly. The availability cash are enough will really help a soldiers in determining the business activities. In watching the flow of cash needed cash flow statements because with it in soldiers are associated with the receipt of cash and spending cash and an assessment of the business activities (operations, investment, and funding) associated with cas. This research aimed at finding out: (1) the report cash flow of the LPD Pakraman Penglatan village period 2013/2014 (2) analysis the report cash flow of the LPD Pakraman Penglatan village period 2013/2014.

The object of this research is the cash flow report and the analysis cash flow of Penglatan LPD. The method which used in this research is documentation. Then the data which has been collected was processed by using quantitative descriptive analysis
\end{abstract}

Keyword : Analysis,Cash The flow, and LPD Pakraman Penglatan village.

\section{PENDAHULUAN}

Pembangunan nasional suatu bangsa mencakup di dalamnya pembangunan ekonomi. Pembangunan ekonomi tersebut tentu sangat tergantung pada perkembangan dan peranan dari Lembaga Keuangan baik lembaga keuangan bank maupun non bank, seperti halnya di provinsi Bali terdapat adanya Lembaga Perkreditan Desa (LPD). LPD tersebut didirikan dengan tujuan untuk membantu masyarakat Desa. Aktivitas LPD dalam kegiatan operasionalnya bersumber dari dana masyarakat atau biasa dikenal dengan dana pihak ketiga berupa tabungan dan deposito. Dana-dana yang dikumpulkan dari masyarakat itu kemudian dikontribusikan kembali kepada masyarakat dalam bentuk kredit sehingga dapat dikatakan kedudukan LPD dalam masyarakat mempunyai peran penting dalam roda perekonomian Desa Pakraman (Pertamawati, 2009:64).

Berdasarkan Perda Propinsi Bali No. 3 Tahun 2007 Pasal 7 ayat 1 tentang lapangan usaha LPD tersebut, dapat diketahui bahwa kegiatan opearional LPD menyerupai kegiatan Bank Perkreditan Rakyat (Kajian Ekonomi Regional Propinsi Bali Triwulan III,2007:45), yaitu sama-sama sebagai lembaga penghimpun dan penyalur dana kepada masyarakat (Hasibuan,2008:38). Hanya saja, BPR dalam ruang lingkup masyarakat luas, sementara LPD hanya pada lingkungan komunitas atau masyarakat desa pakraman (Putra,2011:63). 
LPD dalam melakukan pelaporan terhadap laporan tahunannya tidak banyak yang menyertakan laporan arus kas, sehingga pihak-pihak yang berkepentingan tidak mengetahui dengan jelas mengenai informasi penerimaan kas masuk maupun pengeluaran kas keluar serta penilaian terhadap kegiatan usaha (operasi, investasi, dan pendanaan) yang terkait dengan kas. Aktivitas LPD dalam kegiatan operasionalnya bersumber dari dana masyarakat atau biasa dikenal dengan dana pihak ketiga berupa tabungan dan deposito. Dana-dana yang dikumpulkan dari masyarakat itu kemudian dikontribusikan kembali kepada masyarakat dalam bentuk kredit sehingga dapat dikatakan kedudukan LPD dalam masyarakat mempunyai peran penting dalam roda perekonomian Desa Pakraman (Pertamawati, 2009:64).

LPD dalam mencapai tujuannya perlu mengetahui perkembangan kegiatan usahanya dari waktu-kewaktu, serta perlu juga mengetahui keadaan keuangannya pada saat tertentu agar dapat diketahui apakah mengalami kemajuan atau kemunduran. Salah satunya mengenai penerimaan kas serta pengeluaran kas. Asset dalam LPD yang berwujut uang kas merupakan suatu variable yang penting bagi LPD. Uang kas ini memduduki posisi yang sentral, karena seluruh kegiatan yang ada didalam LPD akan terkait dengan uang kas. Hal ini dapat dilihat dalam salah satu laporan keuangan yaitu laporan arus kas. Didalam laporan arus kas tersebut dapat dilihat arus kas masuk dan arus kas keluar dari kegiatan usaha yang dapat digunakan sebagai suatu alat analisa keuangan yang sangat penting bagi pihak yang terkait dalam pengambilan suatu keputusan. . Memasuki era globalisasi perekonomian saat ini, banyak perkembangan atas perbaikan yang telah dilakukan oleh organisasi LPD. Salah satunya adalah "LEMBAGA PERKREDITAN DESA (LPD)". LPD Desa Pakraman penglatan merupakan salah satu Lembaga Perkreditan Desa (LPD) simpan pinjam yang berada di Singaraja. Seperti layaknya LPD lain, LPD Desa Pakraman Penglatan sangat membutuhkan informasi yang terdapat didalam suatu laporan keuangan khususnya pada laporan arus kas, karena dengan adanya laporan arus kas maka LPD Desa Pakraman Penglatan akan dapat mengetahui sampai sejauh mana perkembangan terhadap kas yang ada didalam LPD tersebut terkait dengan penerimaan/kas masuk maupun pengeluaran/kas keluar.

Di LPD Desa Pakraman Penglatan dalam melakukan pelaporan terhadap laporan tahunannya tidak menyertakan laporan arus kas, sehingga pihak-pihak yang berkepentingan tidak mengetahui dengan jelas mengenai informasi penerimaan/kas masuk maupun pengeluaran/kas keluar serta penilaian terhadap kegiatan usaha (operasi, investasi, dan pendanaan) yang terkait dengan kas.

\section{METODE PENELITIAN}

Tujuan dari penelitian ini adalah untuk mengetahui arus kas pada Lembaga Perkreditan Desa (LPD) Desa Pakraman Penglatan periode 2013-2014. Pada penelitian ini, data yang dipergunakan adalah data kuantitatif yang merupakan fokus utama dari tujuan penelitian. Data kuantitatif yang diperlukan meliputi laporan keuangan selama periode 20132014 yang meliputi neraca komparatif, laporan SHU, dan informasi tambahan lain yang dipergunakan guna dalam penyusunan laporan arus kas.

Teknik analisis data yang digunakan adalah deskriptif kuantitatif yaitu merupakan suatu metode pengelolaan data dengan cara menganalisis dengan menggunakan perhitungan metematis berdasarkan informasi yang didapat mengenai arus kas pada Lembaga Perkreditan Desa (LPD) Desa Pakraman Periode 2013-2014. Selain data kuantitatif, yang menjadi sumber data penelitian ini adalah data sekunder yaitu data yang diperoleh dari dokumen dan catatan-catatan yang berkaitan dengan penelitian. Teknik dalam pengumpulan data yang akan digunakan dalam memperoleh data-data tersebut adalah metode wawancara dan metode dokumentasi.

Berdasarkan data yang diperoleh, kemudian disusun laporan arus kas periode 20132014, selanjutnya dilakukan analisis arus kas terhadap laporan arus kas yang telah disusun. Analisis yang digunakan adalah analisis horizontal dengan menggunakan pendekatan year to year yang menyajikan kenaikan ataupun penurunan masing-masing pos dalam laporan arus kas dari tahun 2013-2014. 


\section{HASIL DAN PEMBAHASAN Laporan Arus Kas Lembaga Perkreditan Desa (LPD) Desa Pakraman Penglatan periode 2013-2014.}

Penyusunan laporan arus kas Pada Lembaga Pekreditan Desa (LPD) Desa Pakraman Penglatan Periode 2013-2014 dapat dilakukan dengan cara menganalisis neraca komparatif, laporan sisa hasil usaha (SHU), dan informasi lainnya pada periode tersebut. Berdasarkan informasi dari neraca komparatif periode 2013-2014, laporan SHU periode 2013-2014, yang pertama yaitu tahun 2013 diketahui bahwa jumlah asset dari sisi aktiva adalah sebesar Rp.22.658.441.000,00 jumlah aktiva ini terdiri dari aktiva lancar yaitu kas sebesar Rp.137.001.000,00, tabungan sebesar Rp.3.519.083.000,00, deposito sebesar Rp.1.400.000.000,00, pinjaman yang diberikan Rp.17.386.498.000,00, dan sebagai akun pengurang piutang ragu-ragu sebesar Rp.350.000.000,00 atau dengan kata lain jumlah aktiva lancar dalam komponen aktiva adalah sebesar Rp.22.092.582.000,00 selanjutnya aktiva yang yang terdiri dari harga perolehan, inventaris dan aktiva tetap sebesar Rp.926.851.000,00 kemudian akun pengurang yaitu akumulasi penyusutan inventaris dan aktiva tetap sebesar Rp.668.144.000,00 dan terakhir rupa-rupa aktiva sebesar Rp.307.152.000,00 dengan kata lain jumlah aktiva tetap sebesar Rp.565.859.000,00 sementara pada sisi pasiva yang komponen kewajiban terdiri dari tabungan wajib sebesar Rp.227.370.000,00, tabungan sukarela sebesar Rp.7.624.080.000,00, simpanan berjangka sebesar Rp.10.558.200.000,00 dan terakhir rupa-rupa pasiva sebesar Rp.304.585.000,00 atau jumlah kewajiban adalah sebesar Rp.18.714.235.000,00 kemudian pada komponen modal lpd terdiri dari modal dasar sebesar Rp.4.500.000, modal donasi sebesar Rp.64.044.000,00 cadangan umum sebesar Rp.2.832.484.000,00 dan terakhir laba Rp.1.043.178.000,00 atau dengan kata lain jumlah modal yang dimiliki lpd Rp.3.944.206.000,00 sedangakan dalam hal sisa hasil usaha Ipd di tahun 2013 dapat diketahui bahwa komponen pendapatan yang terdiri dari pendapat bunga sebesar Rp.317.298.000,00 dari pinjaman yang diberikan Rp.3.400.967.000,00, dan pendapat lainnya sebesar Rp.519.537.000 dengan kata lain jumlah pendapatan yang diperoleh adalah sebesar Rp.4.237.802.000 di sisi lain sebagai akun pengutang biaya operasional lpd dari biaya bunga simpanan berjangka adalah sebesar Rp.975.087.000,00, biaya bunga tabungan sebesar Rp.229.964.000,00, biaya tenaga kerja Rp.941.985.000,00 berikutnya penyusutan aktiva tetap dan inventaris sebesar Rp.140.000.000,00, penyusutan piutang sebesar Rp,50.000.000,00, barang dan jasa dari pihak ketiga sebesar Rp.857.588.000,00 dengan kata lain akun pengurang , jumlah pendapat atau total biaya operasional adalah sebesar Rp3.194.624.000,00 sehingga laba bersih yang diperoleh adalah sebesar Rp.1.043.178.000,00. Sedangkan pada tahun 2014 yaitu diketahui bahwa jumlah asset dari sisi aktiva adalah sebesar Rp.27.056.839.000,00 jumlah aktiva ini terdiri dari aktiva lancar yaitu kas sebesar Rp.236.930.000,00, tabungan sebesar Rp.3.439.593.000,00, deposito sebesar Rp.350.000.000,00, pinjaman yang diberikan Rp.22.708.284.000,00, dan sebagai akun pengurang piutang ragu-ragu sebesar Rp.470.000.000,00 atau dengan kata lain jumlah aktiva lancar dalam komponen aktiva adalah sebesar Rp.26.264.807.000,00 selanjutnya aktiva yang yang terdiri dari harga perolehan inventaris dan aktiva tetap sebesar Rp.946.176.000,00 kemudian akun pengurang yaitu akumulasi penyusutan inventaris dan aktiva tetap sebesar Rp.768.144.000,00 dan terakhir rupa-rupa aktiva sebesar Rp.614.000.000,00 dengan kata lain jumlah aktiva tetap sebesar Rp.792.032.000,00 sementara pada sisi pasiva yang komponen kewajiban terdiri dari tabungan wajib sebesar Rp.229.104.000,00, tabungan sukarela sebesar Rp.909.415.400.000,00, simpanan berjangka sebesar Rp.1.133.940.000.000,00, pinjaman yang diterima sebesar Rp.1.249.999.000,00 dan terakhir rupa-rupa pasiva sebesar Rp.152.564.000,00 atau jumlah kewajiban adalah sebesar Rp.22.135.221.000,00 kemudian pada komponen modal Ipd terdiri dari modal dasar sebesar Rp.4.500.000, modal donasi sebesar Rp.64.044.000,00 cadangan umum sebesar Rp.3.458.391.000,00 dan terakhir laba Rp.1.394.683.000,00 atau dengan kata lain jumlah modal yang dimiliki Ipd pada tahun 
2014 adalah sebesar Rp.4.921.618.000,00 sedangakan dalam hal sisa hasil usaha Ipd di tahun 2014 dapat diketahui bahwa komponen pendapatan yang terdiri dari pendapat bunga sebesar Rp.234.901.000,00, dari pinjaman yang diberikan adalah sebesar Rp.4.565.511.000,00, dan pendapat lainnya sebesar Rp.514.491.000,00 dengan kata lain jumlah pendapatan yang diperoleh Ipd pada tahun 2014 adalah sebesar Rp.5.314.903.000,00 di sisi lain sebagai akun pengurang yaitu biaya operasional Ipd dari biaya bunga lainnya adalah sebesar Rp.80.260.000,00, biaya bunga simpanan berjangka adalah sebesar Rp.1.333.107.000,00, biaya bunga tabungan sebesar Rp.234.089.000,00, biaya tenaga kerja Rp.1.144.938.000,00 berikutnya penyusutan aktiva tetap dan inventaris sebesar Rp.100.000.000,00, penyusutan piutang sebesar Rp.120.000.000,00, barang dan jasa dari pihak ketiga sebesar Rp.907.826.000,00 dengan kata lain akun pengurang , jumlah pendapat atau total biaya operasional adalah sebesar Rp3.920.220.000,00 sehingga laba bersih yang diperoleh pada tahun 2014 adalah sebesar Rp.1.394.683.000,00.

Berdasarkan neraca dan laporan laba rugi maka dapat disusun laporan arus kas dengan menggunakan metode Tidak Langsung. Karena metode tidak langsung menyajikan penerimaan dan pembayaran kas operasi. Metode tidak langsung lebih konsisten dengan tujuan laporan arus kas untuk menyediakan informasi tentang penerimaan dan pembayaran kas dibandingkan dengan metode langsung, yaitu tidak melaporkan penerimaan dan pembayaran kas operasi (keiso, 2002:396). Metode tdak langsung adalah metode yang sederhana, yang hanya terdiri dari arus kas operasi yang dikelompokkan mejadi dua ketegori yaitu Kenaikan kas Dan Penurunan Kas. Dengan metode ini, rekening penghasilan dan biaya yang dilaporkan dengan basis akrual dikonversikan menjadi penghasilan dan biaya berbasis kas (Prastowo, 2005:31-32).

\section{PEMBAHASAN}

\section{Penyajian Laporan Arus Kas}

Berdasarkan penyajian laporan arus kas tersebut selama periode 2013-2014, maka dapat terlihat hal-hal sebagai berikut.

a. Kegiatan Operasi

Pada kegiatan operasi dapat terlihat arus kas masuk dan arus kas keluar barasal dari pos-pos dalam laporan SHU. Dimana pos-pos dalam SHU disesuaikan dari basis akrual menjadi basis kas. Arus kas dari kegiatan operasi ini merupakan perhitungan dari pendapatan dan biaya pada laporan SHU serta disesuaikan dengan penyesuaian yang berkaitan dengan kegiatan ini. Selain itu terdapat penyesuaian terhadap cadangan kerugian piutang dan penyusutan aktiva tetap, namun cadangan kerugian piutang dan penyusutan aktiva tetap tidak dimasukkan ke dalam kegiatan operasi, karena pos ini tidak mempengaruhi penerimaan maupun pengeluaran kas.

b. Kegiatan Investasi

Dalam kegiatan investasi ini dapat diketahui bahwa jumlah kas yang dikeluarkan LPD Desa Pakraman Penglatan digunakan untuk pembelian inventaris.

c. Kegiatan Pendanaan

Dari kegiatan pendanaan yang terjadi di LPD desa pakraman penglatan dapat terlihat bahwa penerimaan dan pengeluaran kas berasal dari kewajiban dan kekayaan bersih yang tidak mempengaruhi laporan SHU. Dimana kegiatan pendanaan hanya mempengaruhi kewajiban dan kekayaan bersih koperasi. Diantaranya adalah perubahan terhadap pos simpanan berjangka, pinjaman yang diterima, rupa-rupa pasiva, modal donasi, cadangan umum.

Berdasarkan hasil yang diperoleh pada laporan arus kas, dapat terlihat penurunan kas pada tahun 2013 dan kenaikan kas pada tahun 2014. Penurunan kas disebabkan karena kegiatan operasional dan investasi menghasilkan aliran kas yang negatif sedangkan kegiatan pendanaan menghasilkan aliran kas yang positif. LPD melakukan kegiatan operasional dan investasi yang sebagian dibiayai dengan dana pinjaman atau penarikan modal. Sebagian dana digunakan untuk operasional dan 
investasi yang berarti penerimaan kas dari masing-masing kegiatan tersebut lebih kecil dari pengeluaran kas. Sehingga dalam jangka panjang cadangan kas yang ada akan habis. Sedangkan kenaikan kas kebalikan dari penurunan kas yaitu disebabkan karena semua kegiatan (operasional, investasi dan keuangan) menghasilkan aliran kas yang positif yang berarti penerimaan kas dari masing-masing kegiatan tersebut lebih besar dari pengeluaran kas.

\section{Analisis Laporan Arus Kas LPD Desa Pakraman Penglatan Periode 2013-2014}

Dari hasil perbandingan tersebut, maka dapat terlihat penurunan kas sebasar (Rp137.244.000,00) atau (368\%), yaitu dari tahun 2013 sebesar (Rp.37.315.000,00) menjadi sebesar (Rp.99.929.000,00) pada tahun 2014. Hal ini disebabkan karena adanya penurunan kas pada masing-masing pos setiap kegiatan. Perubahan-perubahan yang dimagsudkan adalah.

\section{a. Kegiatan Operasi}

Dalam kegiatan operasi terdapat peningkatan sebesar Rp. 2.264.070.000,00 atau 69\%\% yaitu pada tahun 2013 sebesar (Rp. 3.299.875.000,00) menjadi (Rp. 1.035.805.000,00) pada tahun 2014. Ini berarti penerimaan kas lebih besar dari pada pengeluaran kas. Peningkatan arus kas bersih dari kegiatan operasi dipengaruhi oleh hal-hal berikut.

1) Penerimaan Kas Operasional

a. Laba Bersih

Laba bersih ini merupakan laba yang didapat pada tahun 2013 yang dapat dilihat pada laporan SHU. Laba bersih mengalami kenaikan sebesar Rp. 351.505.000,00 dengan persentase 34\%, yaitu sebesar Rp.1.043.178.000,00 pada tahun 2013 menjadi Rp. 1.394.683.000,00 ditahun 2014.

b. Penyusutan Piutang

Penyusutan piutang mengalami kenaikan sebesar Rp.70.000.000,00 atau $140 \%$, yaitu sebesar Rp.50.000.000,00 pada tahun 2013 menjadi Rp.120.000.000 pada tahun 2014.

c. Penurunan Pada Antar Bank Tabungan

Terjadinya penurunan tabungan antar bank sebesar (Rp.943.150.000,00) atau $-92 \%$, yaitu sebesar $1.022 .640 .000,00$ pada tahun 2013 menjadi sebesar Rp.79.490.000,00 pada tahun 2014.

d. Kenaikan Tabungan Wajib

Tabungan wajib mengalami kenaikan sebesar Rp.13.079.000,00 atau 22\%, yaitu sebesar Rp.58.655.000,00 pada tahun 2013 dan sebesar Rp.71.734.000,00 pada tahun 2014.

e. Tabungan Sukaela

Tabungan sukarela mengalami kenaikan sebesar Rp.1.567.255.000,00 atau $1613 \%$, yaitu sebesar (Rp.97.181.000,00) pada tahun 2013 menjadi Rp.1.470.074.000,00 pada tahun 2014.

2) Pengeluaran Kas Operasional

a. Penyusutan

Penyusutan mengalami penurunan sebesar (Rp. 40.000.000,00) dengan prosentase $-29 \%$ dikarenakan pada tahun 2013 besar penyusutan Rp.140.000.000,00 menjadi Rp.100.000.000,00 pada tahun 2014.

b. Kenaikan Deposito Antar Bank

Kenaikan deposito antar bank ini akan mengakibatkan berkurangnya jumlah kas yang ada. Jumlah deposito mengalami kenaikan sebesar Rp.1.750.000.000,00 atau $-250 \%$, yaitu sebesar (Rp.700.000.000,00) pada tahun 2013 menjadi sebesar Rp.1.050.000.000 pada tahun 2014.

c. Kenaikan Pinjaman Yang Diberikan

Bertambahnya jumlah pinjaman yang diberikan secara langsung akan mengurangi jumlah kas yang tersedia. Jumlah pinjaman yang diberikan 
mengalami kenaikan sebesar Rp.504.619.000,00 atau 10\%, yaitu sebesar (Rp.4.817.167.000,00) pada tahun 2013 menjadi sebesar (Rp.5.321.786.000,00) pada tahun 2014.

\section{b. Kegiatan investasi}

Kenaikan inventaris sebesar Rp.1.635.000,00 atau $-8 \%$,yaitu sebesar (Rp.20.960.000,00) pada tahun 2013 kemudian menjadi (Rp.19.325.000,00) pada tahun 2014. Sedangkan pada rupa-rupa aktiva mengalami penurunan sebesar (Rp.969.696.000,00) atau $-146 \%$, yaitu sebesar Rp.662.848.000,00 pada tahun 2013 menjadi (Rp.306.848.000,00) ditahun 2014.

c. Kegiatan pendanaan

Pada kegiatan pendanaan terjadi penurunan, ini berarti arus kas masuk lebih kecil dibandingkan arus kas keluar. Selama periode 2013-2014 terjadi penurunan arus kas bersih dari kegiatan pendanaan sebesar (Rp. 1.158.765.000,00) atau $-44 \%$, yaitu sebesar Rp.2.620.672.000,00 pada tahun 2013 menjadi Rp.1.461.907.000,00 pada tahun 2014. Penurunan arus kas bersih dari kegiatan pendanaan selama periode 2013-2014 dikarenakan arus kas masuk lebih kecil dibandingkan dengan arus kas keluar pada pengeluaran ekstern maupun intern LPD. Penurunan tersebut dipengaruhi oleh hal-hal berikut :

1) Simpanan Berjangka

Simpanan berjangka mengalami penurunan sebesar Rp.2.129.700.000,00 atau $-73 \%$, yaitu sebesar Rp.2.910.900.000,00 sedangkan pada tahun 2014 sebesar Rp.781.200.000,00. Hal ini terjadi dikarenakan berkurangnya jumlah simpanan berjangka yang ada di LPD dari tahun 2013 ke tahun 2014.

2) Pinjaman yang Diterima

Pinjaman yang diterima mengalami kenaikan sebesar Rp.1.279.999.000,00 atau $-426 \%$, yaitu sebesar (Rp.30.000.000,00) pada tahun 2013 menjadi Rp.1.249.999.000,00 pada tahun 2014. Hal ini terjadi karena bertambahnya jumlah pinjaman yang diterima oleh pihak LPD.

1) Rupa-Rupa Pasiva

Rupa-rupa pasiva mengalami penurunan sebesar Rp.156.016.000,00 atau $3905 \%$, yaitu sebesar Rp.3.995.000,00 pada tahun 2013 menjadi (Rp.152.021.000,00) pada tahun 2014. Hal ini terjadi karena berkurangnya jumlah rupa-rupa pasiva yang ada.

2) Modal Donasi

Modal Donasi mengalami penurunan sebesar Rp.30.000.000,00 atau 100\% yaitu sebesar Rp.30.000.000,00 pada tahun 2013 menjadi Rp.0,00 pada tahun 2014. Hal ini terjadi karena tidak adanya modal donasi baru pada periode 2014.

3) Cadangan Umum

Cadangan Umum mengalami peningkatan sebesar Rp.184.572.000,00 atau $42 \%$ yaitu sebesar Rp.441.335.000,00 pada tahun 2013 menjadi Rp.625.907.000,00 pada tahun 2014.

4) Laba

Laba mengalami penurunan sebesar Rp.307.620.000,00 atau 42\% yaitu sebesar Rp.735.558.000,00 pada tahun 2013 menjadi Rp.1.043.178.000,00 pada tahun 2014.

Berdasarkan uraian diatas, dapat terlihat kas pada tahun 2013 bernilai negatif karena dari arus kas masuk kegiatan operasi mengalami penurunan dibandingkan kegiatan Investasi dan keuangan/pendanaan. Sehingga berdasarkan analisis, maka pada tahun 2013 dapat terlihat arus kas dari kegiatan operasi menghasilkan aliran kas negatif, sedangkan investasi dan keuangan/pendanaan menghasilkan aliran kas yang positif. Sedangkan pada tahun 2014 dari kegiatan operasional menghasilkan aliran kas yang positif dan kegiatan investasi dan pendanaan/keuangan mengalami aliran kas yang negatif. 


\section{Simpulan Dan Saran}

Berdasarkan hasil analisis yang dilakukan atas laporan keuangan LPD Desa Pakraman Penglatan yang telah diuraikan pada Bab IV, maka dapat ditarik suatu simpulan menganai analisis laporan arus kas pada LPD Desa Pakraman Penglatan periode 2013-2014 adalah sebagai berikut.

1) Kas pada tahun 2013 mengalami penurunan yaitu sebesar Rp. 37.315.000,00, karena kegiatan operasional menghasilkan aliran kas yang negative yang sangat besar sedangkan kegiatan keuangan/ dan Inveastasi menghasilkan aliran kas yang positif. LPD Desa Pakraman Penglatan dalam melakukan kegiatan operasional yang sebagian dibiayai dengan dana pinjaman atau penarikan modal. Ini berarti penerimaan dari masing-masing kegiatan yaitu operasional lebih kecil dari pada pengeluaran dari masing-masing kegiatan tersebut. Kas pada tahun 2014 mengalami peningkatan yaitu sebesar Rp. 99.929.000,00, karena kegiatan pendanaan/keuangan menghasilkan aliran kas yang positif yang sangat besar.

2) Kas selama periode 2013-2014 mengalami peningkatan sebesar Rp. 137.244.000 atau $368 \%$, yaitu dari tahun 2013 sebesar Rp. (37.315.000) menjadi sebesar Rp.99.929.000 pada tahun 2014.

\section{Daftar Pustaka}

Ikatan Akuntan Indonesia (IAI). (2002). Pernyataan Standar Akuntansi Keuangan (PSAK). Salemba Empat, Jakarta.

Keiso, Donald E. dkk. 2007. Akuntansi Intermediate Jilid 1. Edisi Keduabelas. Jakarta : Erlangga

Legowo M, Anang dkk. 2005. Analisis pangan. Semarang : Badan Penerbit Universitas Diponegoro

Mardiasmo. 1993. Akuntansi Keuangan Dasar 1. Edisi Kedua. Yogyakarta : BPFE

Niswonger, C. Rollin dkk. 1997. Prinsip-Prinsip Akuntansi Jilid 2. Edisi Keenambelas. Jakarta : Erlangga

Nurhuda, Arif. 2009. Dasar-Dasar Akuntansi. 14 September. http://dasarakuntansi.blogspot.com/2009/09/laporan-arus-kas.html

Prastowo, Dwi dan Rifka Juliati. 2005. Analisis Laporan Keuangan. Konsep dan Aplikasi. Edisi Revisi. Yogyakarta : Unit Penerbit dan Percetakan Akademi

Soemarso. 1999. Akuntansi Suatu Pengantar. Edisi Keempat. Jakarta : PT. Rineka Cipta

Sitio, Arifin dan Tamba, Halomon. 2001. Koperasi Teori dan Praktek. Jakarta : Erlangga.

Sebayang, Gustevan Putra. 2008. Analisa Laporan Arus Kas Pada PO. Medan Jaya. Medan : Universitas Sumatera Utara Medan

Dharmayuda, I Made suasthawa. 2001. Kesatuan Masyarakat Hukum Adat di Provinsi Bali. Denpasar: Upada Sastra.

Per. "Pemberdayaan aturan Daerah Provinsi Bali Nomor 3 Tahun 2007 tentang Perubahan Atas Peraturan Daerah Provinsi Bali Nomor 8 Tahun 2002 Tentang Lembaga Perkreditan Desa. http://ditjenpp.kemenkumham.go.id/files/ld/2007/ProvinsiBali-32007.pdf. Download Tanggal 22 April 2014.

Peraturan_Daerah Provinsi Bali Nomor 8 Tahun 2002 Tentang Lembaga Perkreditan Desa. http://www.google.com/url?sa $=$ t\&rct=i\&q=\&esrc=s\&source $=$ web\&cd $=1 \& v e d=0 C C c Q$ FjAA\&url=http\%3A\%2F\%2Fwww.bphn.go.id\%2Fdata\%2Fdocuments\%2F02pdbali0 08.doc\&ei=vldWU4yRDsjlrAeYaA\&usg=AFQjCNE67kSSSgvAg854 W0SUMbsO0ti Mw\&sig2=QZoF IhD6u54pYz iRvt9A. Download Tanggal 20 April 2014 
Pertamawati, Ni Putu. 2010 Lembaga Perkreditan Desa (LPD) Dalam Mendorong Penggalian Dana Pembangunan Pedesaan di Provinsi Bali”. Sarathi Vol. 15 No. 1 Januari 2008. http://isjd.pdii.lipi.go.id/index.php/Search.html?act=tampil\&id=63334\&idc=72. Download Tanggal 22 April 201

Putra, I.B. Wyasa (Eds). 2011. Landasan Teoretik Pengaturan LPD sebagai Lembaga Keuangan Komunitas Masyarakat Hukum Adat Di Bali. Cetakan Pertama. Denpasar: Udayana University Press.

Setiawan, I Made Budhi. 2013. Peraturan Gubernur Bali Nomor 11 Tahun 2013 Tentang Lembaga Perkreditan Desa (LPD). Bagian Perekonomian Dan Pembangunan SETDA Kabupaten Buleleng. 